Wiesława Gierańczyk*, Agata Sadoch ${ }^{* *}$

\title{
REGIONALNE ZRÓŻNICOWANIE AKTYWNOŚCI PRZEDSIĘBIORSTW PRZEMYSŁOWYCH W ZAKRESIE WYKORZYSTANIA FINANSOWYCH INSTRUMENTÓW PUBLICZNEGO WSPARCIA INNOWACJI W OKRESIE 2011-2013
}

S Ło w a k 1 u c z o w e: konkurencyjność; działalność innowacyjna; publiczne wsparcie działalności innowacyjnej.

Z a r y s t r e ś c i: Innowacje kojarzone są z postępem i nowoczesnością, a ich dyfuzja do sfery praktycznego funkcjonowania przyczynia się w dużej mierze do rozwoju gospodarczego. Stanowią one siłę napędową rozwoju gospodarki, są bowiem specyficznymi narzędziami przedsiębiorczości.

Pomimo że korzyści płynące z bycia innowacyjnym są powszechnie znane i akceptowane, to aktywność innowacyjna polskich przedsiębiorstw nie jest duża. Jedną z poważniejszych barier uruchamiania procesów innowacyjnych są koszty. Często przekraczają one możliwości przedsiębiorstw. Obecnie na polskim rynku dostępne są instrumenty wspomagające finansowanie innowacji. W niniejszym artykule przeanalizowano aktywność przedsiębiorstw przemysłowych w zakresie wykorzystania finansowych instrumentów publicznego wsparcia innowacji. Uwzględniono przy tym wielkość aktywnych innowacyjnie przedsiębiorstw przemysłowych i ich

* Adres do korespondencji: Wiesława Gierańczyk, Urząd Statystyczny w Bydgoszczy, Oddział w Toruniu, ul. Mickiewicza 10/16, 87-100 Toruń, e-mail: w.gieranczyk@stat.gov.p

** Agata Sadoch, Urząd Statystyczny w Bydgoszczy, ul. Mickiewicza 10/16, 87-100 Toruń, e-mail: a.sadoch@stat.gov.pl. 
lokalizację według województw. Przeanalizowano zarówno wykorzystanie wsparcia krajowego, jak i z UE, a także zbadano programy celowe, w zakresie których takie wsparcie zostało udzielone. Podstawę analiz stanowiły dane GUS z badania PNT-02 przeprowadzonego w $2014 \mathrm{r}$.

Klasyfikacja JEL: O30.

\section{WSTĘP}

Innowacje kojarzone są z postępem i nowoczesnością. W warunkach wzrastającej konkurencji innowacje i związane z nimi zmiany, nowości oraz zdolność i gotowość do ich poszukiwania, tworzenia, absorpcji i wprowadzania w praktyce gospodarczej odgrywają niekwestionowaną rolę w rozwoju podmiotów gospodarczych, regionów i całych gospodarek (Stawisz, 2010, s. 123). Najczęściej rozumiane są jako wdrożenie nowego lub istotnie ulepszonego produktu (wyrobu lub usługi) czy procesu, nowej metody organizacyjnej bądź nowej metody marketingowej w praktyce gospodarczej, organizacji miejsca pracy lub stosunkach $z$ otoczeniem ${ }^{1}$. Jak wynika z przytoczonej definicji, produkty, procesy oraz metody organizacyjne i marketingowe nie muszą być nowością dla rynku, na którym operuje przedsiębiorstwo, ale muszą być nowością przynajmniej dla samego przedsiębiorstwa. Produkty, procesy i metody nie muszą być opracowane przez samo przedsiębiorstwo, mogą być opracowane przez inne przedsiębiorstwo bądź przez jednostkę o innym charakterze (np. instytut naukowo-badawczy, ośrodek badawczo-rozwojowy, szkołę wyższą itp.) (Gierańczyk i Kordowska, 2014, s. 51).

Obserwowane współcześnie dążenie do wzrostu innowacyjności i związanej z nią przedsiębiorczości i konkurencyjności wynika m.in. z upowszechniania modelu nowoczesnej gospodarki opartej na wiedzy. Ten typ gospodarki bazuje na potencjale intelektualnym, nauce oraz na innowacjach. Stąd innowacyjność, zwłaszcza w sektorze przemysłowym (Przychodzeń, 2013, s. 106-116), postrzegana jest obecnie jako jeden z najważniejszych czynników decydujących o możliwościach rozwoju gospodarek (w tym regionalnych) oraz ich konkurencyjności. W bardziej współczesnych teoriach rozwoju innowacje postrzegane są jako kluczowy czynnik

1 Słownik pojęć GUS, http://stat.gov.pl/metainformacje/slownik-pojec/definicje-pojec/2596,pojecie.html (2.02.2015) 
rozwoju gospodarczego i wzrostu dobrobytu społecznego (Hettne, 1983, s. 247-266; Mazumdar, 2005, s. 98-120). W tym nurcie mieszczą się też teorie dotyczące istoty i znaczenia wykorzystywania odpowiednich technik produkcji (Schumacher, 1979, s. 345; Sen, 1983, s. 745-762), konieczności stymulowania transformacji strukturalnej i demograficznej (Matsuyama, 1992, s. 383-395) czy intensyfikacji postępu technicznego i inwestowania w czynnik ludzki (Krueger, 1968, s. 641-659; Lucas, 1988 s. 3-42).

Przeprowadzone badania wskazują, że aktywność innowacyjna polskich przedsiębiorstw przemysłowych jest niska (np. Sawa, 2013; Limański 2011), ale występują znaczące różnice w poziomie tej aktywności w układach regionalnych. Dodatkowo zróżnicowanie warunkowane jest wielkością przedsiębiorstw. Stąd celem niniejszego opracowania było ukazanie regionalnych różnic $\mathrm{w}$ postawach przedsiębiorstw przemysłowych pod względem ich aktywności w zakresie wykorzystania finansowych instrumentów publicznego wsparcia innowacji w okresie 2011-2013. Analizowano zarówno wykorzystanie wsparcia krajowego, jak i z UE, przebadano też programy celowe, w zakresie których takie wsparcie zostało udzielone.

\section{MATERIAŁ ŹRÓDŁOWY I METODY BADAWCZE}

Źródło danych do analiz przedmiotowej problematyki stanowiły wyniki „Badania o innowacjach w przemyśle” (PNT-02) przeprowadzonego w 2014 r. Badanie to objęło przedsiębiorstwa prowadzące działalność gospodarczą zaklasyfikowaną według PKD do sekcji B, C, D i E, w których liczba pracujących wynosiła 50 osób lub więcej - badanie pełne - oraz od 10 do 49 osób - próba reprezentacyjna (25\% podmiotów).

Przedmiotem badań w niniejszym opracowaniu była próba delimitacji województw o podobnej, według wielkości przedsiębiorstw, aktywności w zakresie wykorzystania finansowych instrumentów publicznego wsparcia innowacji w okresie 2011-2013. Wielkość przedsiębiorstw określono poprzez liczbę pracujących w nich osób, kwalifikując jako przedsiębiorstwa małe podmioty liczące od 10 do 49 osób, średnie od 50 do 249 osób, duże zaś powyżej 249 osób.

Podstawę analiz stanowiły zmienne obrazujące liczbę aktywnych innowacyjnie przedsiębiorstw przemysłowych, które uzyskały publiczne wsparcie innowacji ze środków krajowych, zagranicznych, a także liczbę przedsiębiorstw przemysłowych, które korzystały z tych środków w ramach programów na: podnoszenie kwalifikacji zawodowych, wsparcie 
współpracy międzynarodowej, wsparcie współpracy krajowej regionalnej, klastrowej, wsparcie eksportu, specjalistyczną pomoc doradczą, wsparcie inwestycji, wsparcie współpracy sfery nauki i przedsiębiorstw, wsparcie działalności badawczo-rozwojowej.

W ocenie zasobów informacyjnych zmiennych w układach regionalnych uwzględniono ich zdolność dyskryminacyjną, czyli zmienność w województwach, oraz ich pojemność informacyjną (potencjał informacyjny), czyli stopień skorelowania zmiennych. Duże i bardzo duże zróżnicowanie przyjętych do analizy zmiennych pozwoliło ocenić ich wartość dyskryminacyjną jako dużą. Natomiast niski poziom skorelowania zmiennych pozwolił założyć dużą pojemność informacyjną. Pojemność informacyjna zmiennej jest bowiem tym większa, im jest ona słabiej skorelowana $\mathrm{z}$ innymi zmiennymi. Podstawę do oceny pojemności informacyjnej stanowiła macierz korelacji potencjalnych zmiennych diagnostycznych

Założoną delimitację wykonano za pomocą metody hierarchicznej klasyfikacji aglomeracyjnej należącej do metod analizy skupień. Hierarchiczna klasyfikacja aglomeracyjna opiera się na centralnej procedurze aglomeracyjnej. Polega ona na znalezieniu pary klas najmniej odległych od siebie (najbardziej podobnych) w macierzy odległości. Po redukcji liczby klas o jeden w kolejnym etapie łączy się wcześniej uzyskane klasy w nową klasę. Następnie przekształca się odległości pomiędzy połączonymi klasami oraz pozostałymi klasami. Etapy te powtarza się tak długo, aż wszystkie obiekty nie znajdą się w jednej klasie. Do wydzielenia skupień województw, po przetestowaniu różnych metod aglomeracyjnych i różnych odległości, zastosowano metodę Warda i odległość euklidesową. Metoda opiera się na minimalizacji sumy kwadratów odchyleń wewnątrz skupień. Na każdym jej etapie spośród wszystkich możliwych do łączenia par skupień wybiera się tę, która w rezultacie łączenia daje skupienie o minimalnym zróżnicowaniu (por. Everitt i in., 2011, s. 77-78; Stanisz, 2007, s. 122). Zastosowanie tej metody pozwoliło w sposób najbardziej jednoznaczny wydzielić skupienia województw najbardziej podobnych wewnątrz skupień i jednocześnie najbardziej różnych między skupieniami.

Analizę empiryczną w zakresie aktywności innowacyjnej przedsiębiorstw przemysłowych oparto na wybranych miarach struktury. Do badania tej aktywności w województwach ogółem i według wielkości przedsiębiorstw wykorzystano wskaźniki obrazujące:

- udział przedsiębiorstw przemysłowych aktywnych innowacyjnie (Pak) w latach 2011-2013, które uzyskały wsparcie publiczne ze środków krajowych, 


$$
\mathrm{Pak}_{\mathrm{k}}=\frac{\mathrm{a}_{\mathrm{k}}}{\mathrm{A}_{\mathrm{og}}} * 100
$$

gdzie:

$a_{k}$ - liczba przedsiębiorstw przemysłowych aktywnych innowacyjnie w latach 2011-2013, które otrzymały publiczne wsparcie działalności innowacyjnej pochodzące ze środków krajowych,

$A_{o g}$ - liczba przedsiębiorstw przemysłowych aktywnych innowacyjnie w latach 2011-2013,

- udział przedsiębiorstw przemysłowych aktywnych innowacyjnie, które w latach 2011-2013 uzyskały wsparcie publiczne ze środków UE,

$$
\operatorname{Pak}_{U E}=\frac{a_{U E}}{\mathrm{~A}_{\mathrm{og}}} * 100
$$

gdzie:

$a_{U E}$ - liczba przedsiębiorstw przemysłowych aktywnych innowacyjnie w latach 2011-2013, które otrzymały publiczne wsparcie działalności innowacyjnej pochodzące ze środków Unii Europejskiej.

W celu ukazania różnic w zakresie uzyskanego publicznego wsparcia na działalność innowacyjną według wielkości przedsiębiorstw wykorzystano empiryczny obszar zmienności.

\section{AKTYWNOŚĆ INNOWACYJNA PRZEDSIĘBIORSTW PRZEMYSŁOWYCH}

Jedną z miar innowacyjności przedsiębiorstw jest ich zaangażowanie w działania innowacyjne. Według definicji GUS przedsiębiorstwo aktywne innowacyjnie to przedsiębiorstwo, które wdrożyło przynajmniej jedną innowację produktową lub procesową bądź prowadziło działalność innowacyjną zaniechaną lub niezakończoną (w tym działalność badawczo-rozwojową, która nie jest bezpośrednio związana z tworzeniem konkretnej innowacji). W Polsce w latach 2011-2013 działalność innowacyjną w tym rozumieniu prowadziło $18,4 \%$ przedsiębiorstw przemysłowych. Wskaźnik ten wahał się od $15,2 \% \mathrm{w}$ województwie kujawsko-pomorskim do $24,2 \%$ w województwie podlaskim (ryc. 1). 


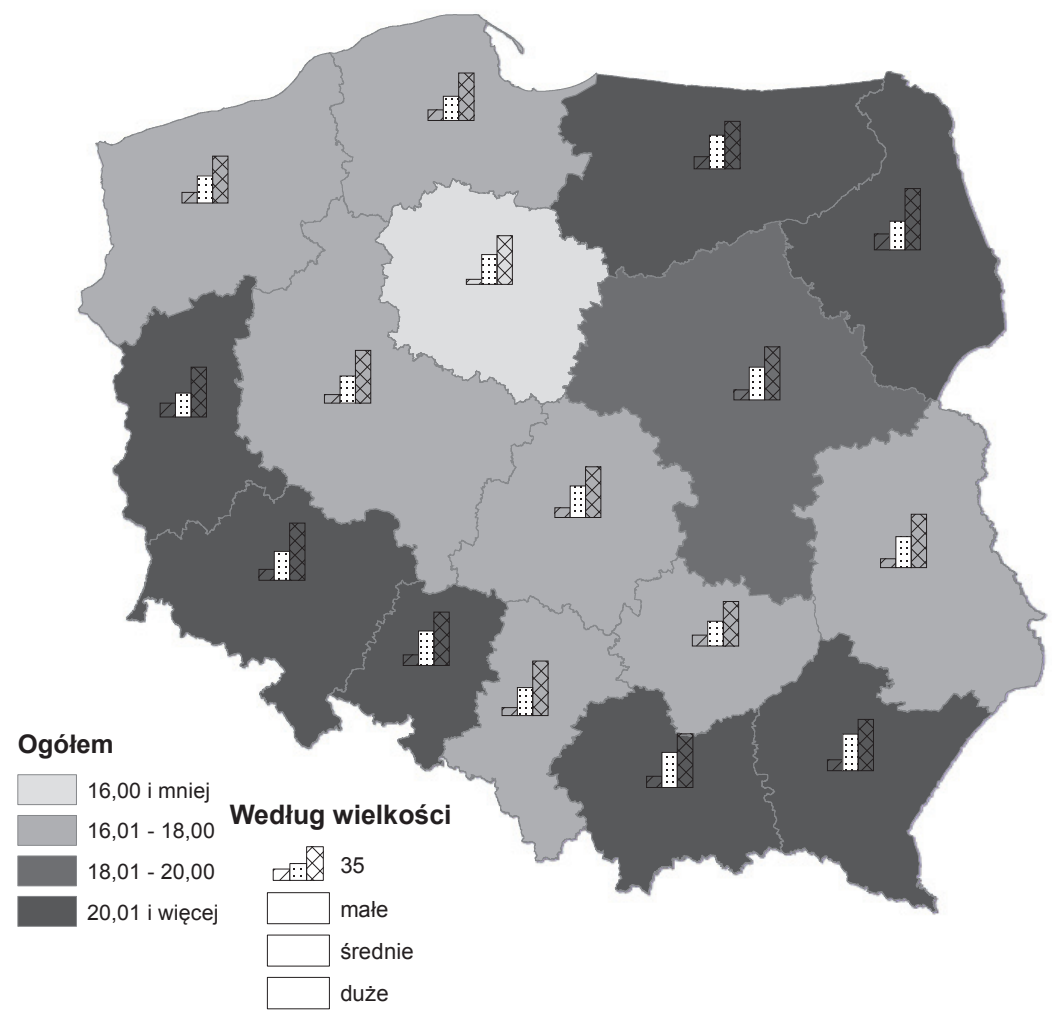

Ryc. 1. Przedsiębiorstwa przemysłowe aktywne innowacyjnie w latach 2011-2013 w ogólnej liczbie przedsiębiorstw przemysłowych (\%)

Źródło: opracowanie własne na podstawie danych GUS.

Analiza danych wykazała, że w rozpatrywanym okresie niezależnie od ogólnego poziomu aktywności innowacyjnej przedsiębiorstw przemysłowych, zarówno w kraju ogółem, jak i w poszczególnych województwach, udział podmiotów podejmujących działania innowacyjne wzrastał wraz ze wzrostem wielkości podmiotów. Wraz z wielkością przedsiębiorstw wzrastał również empiryczny obszar zmienności. W analizowanym okresie dla przedsiębiorstw małych wynosił on 12,9 p.p., przy czym najniższa aktywność innowacyjna wśród przedsiębiorstw przemysłowych była na poziomie ok. 5\% (w województwie kujawsko-pomorskim), a dla przedsiębiorstw dużych - 19,2 p.p., przy najniższej aktywności innowacyjnej przedsiębiorstw przemysłowych $\mathrm{w}$ województwie świętokrzyskim - 51,0\%. Mamy zatem sytuację, że najbardziej aktywne innowacyjnie są przedsiębiorstwa stano- 
wiące liczebnie mniejszość. Stąd bardzo często relatywnie wysoka aktywność innowacyjna dużych przedsiębiorstw przemysłowych nie przekłada się na wysoką aktywność innowacyjną przedsiębiorstw w regionie w ogóle. W strukturze polskiej gospodarki i gospodarek regionalnych przeważają bowiem firmy małe i średnie (99,8\% (Piersiala i Nowakowska-Grunt, 2014, s. 144-156)). Zajmują one bardzo ważne miejsce w gospodarce ${ }^{2}$. Pełniąc wiele istotnych funkcji o charakterze ekonomicznym, techniczno-produkcyjnym i społecznym, decydują o rozwoju ekonomicznym regionów oraz kształtowaniu ich konkurencyjności i innowacyjności (Low i Chapman, 2007, s. 878-891; Audretsch, 2001, s. 37-51). Tak więc pomimo relatywnie niskiego poziomu aktywności innowacyjnej małe i średnie przedsiębiorstwa jako całość są ważnym aktorem w procesach innowacyjnych w gospodarce, ale role, które odgrywają poszczególne przedsiębiorstwa, są bardzo zróżnicowane. $Z$ punktu widzenia innowacyjności sektor ten jest wysoce heterogeniczny (Niedzielski, Rychlik, 2006, s. 196 i dalsze). Każde z przedsiębiorstw (lub ich wyodrębnione grupy) ma swoje własne specyficzne zachowania innowacyjne - od prostych imitacji do innowacji radykalnych, od stosunkowo wyizolowanej działalności innowacyjnej do bardzo skomplikowanych powiązań z innymi podmiotami. Rzutuje to na atrakcyjność małych i średnich przedsiębiorstw dla ich partnerów w procesie innowacyjnym (Stawasz, 2011, s. 41), a także ich skłonność do samodzielnego unowocześnienia produktów i wdrożenie takich zmian w portfelu produktów, które dadzą możliwość rozwoju oraz zadowolenia ze spełnienia oczekiwań klientów. W związku z tym konieczne jest poznawanie potrzeb klientów, których wymagania stają się coraz wyższe. Poszukiwanie odpowiedzi na pytania, jak sprostać potrzebom rynku, jakie są jego oczekiwania oraz jak być konkurencyjnym, wymaga od przedsiębiorstw stałego poszukiwania nowatorskich rozwiązań. Aby zyskać przewagę konkurencyjną nad innymi przedsiębiorstwami, coraz więcej firm modyfikuje swoją ofertę, wprowadzając innowacje. Stając się innowacyjnymi, podmioty gospodarcze mają większą szansę na sukces rynkowy. Coraz częściej dla wielu z nich pro-

2 Do nich można m.in. zaliczyć: aktywny udział w procesie zmian struktury przemysłowej kraju wynikającej z demonopolizacji i restrukturyzacji gospodarki; odgrywanie ważnej roli w rozwoju prywatnej własności środków produkcji; zagospodarowanie często ogromnych nadwyżek siły roboczej „uwolnionej” w wyniku racjonalizacji funkcjonowania sektora publicznego; wymuszanie zmian w uregulowaniach prawnych sprzyjających rozwojowi przedsiębiorczości i efektywności funkcjonowania małych podmiotów (za: Piecuch, 2010, s. 18). 
wadzenie działalności innowacyjnej to już nie tylko sposób na uzyskanie przewagi nad konkurencją i zdobycie pozycji lidera, lecz także warunek konieczny utrzymania się na rynku. Zwłaszcza dla małych i średnich firm wprowadzanie nowych produktów, usług czy też technologii okazuje się niezbędne, by np. dotrzymać kroku dużym przedsiębiorstwom. Efektywnie wdrożona innowacja obniża koszty, zwiększa wydajność pracy lub wpływa na oba obszary. Z tego względu polityka proinnowacyjna (Wieser, 2005, s. 587-621) jest coraz bardziej widoczna w większości krajów Unii Europejskiej i w krajach OECD (Griffith i in., 2001, s. 375-399).

\section{FINANSOWANIE DZIAŁALNOŚCI INNOWACYJNEJ}

Korzyści płynące z wdrożenia innowacji są ogromne, zmiany muszą być jednak popierane przez menedżerów, akceptowane przez pracowników i poprzedzone odpowiednimi przygotowaniami tworzącymi podstawy uzyskania pozytywnego efektu z opracowania i wdrożenia użytecznej nowości (Tidd, Bessant, 2011, s. 196 i dalsze). Zatem innowacyjne myślenie o przedsiębiorstwie wymaga podejścia procesowego. Proces innowacji oprócz tego, że zwykle obarczony jest większym poziomem niepewności niż inne procesy biznesowe, wymaga zaangażowania specjalistycznej wiedzy, a także znacznych zasobów materialnych i nakładów finansowych (Frąś, 2013, s. 184-185). Te ostatnie, często przekraczając możliwości przedsiębiorstw (zwłaszcza małych i średnich), stanowią barierę uruchamiania procesów innowacyjnych.

Obecnie na polskim rynku dostępne są bardzo różne instrumenty finansowania, z których mogą skorzystać przedsiębiorstwa prowadzące działalność innowacyjną. Wybór odpowiednich i możliwych do pozyskania instrumentów finansowania projektów innowacyjnych powinien być dostosowany do poziomu rozwoju firmy oraz fazy rozwoju samego projektu innowacyjnego. Ze względu na duże ryzyko niepowodzenia w przypadku projektów innowacyjnych na wczesnym etapie ich rozwoju podstawowym źródłem finansowania pozostają środki własne przedsiębiorstwa. Nieco później, kiedy projekt przyjmuje bardziej zaawansowaną formę, przedsiębiorca może skorzystać z zewnętrznych źródeł finansowania pochodzących m.in. od inwestorów prywatnych, tzw. aniołów biznesu, z funduszy seed czy funduszy venture capital (private equity). W fazie wdrożenia projektu źródłem finansowania mogą być przedsiębiorstwa przemysłowe (kapitałowo jako inwestor strategiczny lub korporacyjny inwestor venture capital) 
oraz, choć znacznie rzadziej, kredyty bankowe (wynika to między innymi z niechęci banków wobec przedsięwzięć dużego ryzyka, jakimi często są innowacje). Dla mocno zaawansowanych lub wdrożonych projektów innowacyjnych istnieją możliwości finansowania poprzez instrumenty rynku kapitałowego (np. akcje czy obligacje), przy czym taka forma finansowania najczęściej przeznaczona jest dla dużych lub co najmniej średnich przedsiębiorstw (Głodek i Gołębiowski, 2006, s. 10-12).

$\mathrm{Na}$ wszystkich etapach rozwoju projektu innowacyjnego istnieje także możliwość pozyskania wsparcia publicznego pochodzącego ze źródeł krajowych m.in. poprzez:

- programy Polskiej Agencji Rozwoju Przedsiębiorczości (PARP), wśród których większość przeznaczana jest na wsparcie małych i średnich przedsiębiorstw,

- kredyty technologiczne oferowane przez Bank Gospodarstwa Krajowego na inwestycje technologiczne dotyczące zakupu nowej technologii, jej wdrożenia i uruchomienia,

- wsparcie kapitałowe funduszy VC oraz sektora MSP przez Krajowy Fundusz Kapitałowy, którego celem jest zmniejszenie luki dostępności finansowania dla innowatorów,

- konkursy Narodowego Centrum Nauki oferujące wspólfinansowanie badań podstawowych czy stypendiów dla naukowców,

- konkursy Narodowego Centrum Badań i Rozwoju,

- granty oferowane przez Ministerstwo Edukacji i Nauki na realizację projektów badawczych (celowych) wykonywanych na zlecenie przedsiębiorstw przez ośrodki i zespoły naukowe

- oraz finansowanego ze środków Unii Europejskiej, w tym w ramach programów operacyjnych, które służyły realizacji Narodowej Strategii Spójności 2007-2013, takich jak: Innowacyjna Gospodarka, Kapitał Ludzki, Rozwój Polski Wschodniej czy Regionalnych Programów Operacyjnych (Bukowski, Szpor, Śniegocki, 2012, s. 22-23).

W latach 2011-2013 w polskich przedsiębiorstwach przemysłowych, jak wynika z analizy danych GUS, głównym źródłem finansowania działalności innowacyjnej były środki własne. Pokrywały one ponad $70 \%$ wydatków na działalność innowacyjną. Zauważa się przy tym, że udział środków własnych w finansowaniu działalności innowacyjnej najwyższy był wśród podmiotów dużych, gdzie wyniósł niemal $80 \%$ ogółu nakładów na działalność innowacyjną. Znacznie większe problemy z finansowaniem innowacji z własnych środków miały przedsiębiorstwa małe i średnie. W przypadku podmiotów przemysłowych tej wielkości środki własne stanowiły odpo- 
wiednio ok. 56\% i 51\% ogółu nakładów ponoszonych na działania innowacyjne.

\section{PUBLICZNE WSPARCIE DZIAŁALNOŚCI INNOWACYJNEJ}

Biorąc pod uwagę trudności polskich przedsiębiorstw przemysłowych z wygospodarowywaniem funduszy wewnętrznych na realizację projektów innowacyjnych, można było zakładać, że będą one wykazywały wzmożoną aktywność w pozyskiwaniu funduszy z zewnątrz, zwłaszcza w sektorze małych i średnich przedsiębiorstw. Tymczasem badanie dotyczące okresu 2011-2013 wykazało, że w ogóle aktywność przedsiębiorstw przemysłowych w zakresie pozyskania z publicznego wsparcia - krajowego ( $\mathrm{tj}$. od jednostek samorządu terytorialnego lub terenowych organów administracji rządowej czy jednostek rządowych szczebla centralnego) i z funduszy Unii Europejskiej na realizację innowacyjnych projektów jest relatywnie mała, przy czym zróżnicowana według wielkości podmiotów. W analizowanym okresie w Polsce wśród ogółu aktywnych innowacyjnie przedsiębiorstw przemysłowych zaledwie $1 / 4$ otrzymała publiczne wsparcie na prowadzenie działalności innowacyjnej. Wśród nich największym beneficjentem publicznego wsparcia były przedsiębiorstwa średnie. Otrzymało je niemal $30 \%$ aktywnych innowacyjnie podmiotów tej wielkości. Niższy był odsetek podmiotów, które otrzymały wsparcie publiczne działalności innowacyjnej wśród podmiotów dużych $(25,0 \%)$, natomiast relatywnie najmniej przedsiębiorstw korzystało z publicznych form wsparcia w grupie podmiotów małych. W analizowanym okresie otrzymało je nieco ponad $20 \%$ aktywnych innowacyjnie przedsiębiorstw tej wielkości.

Zdecydowanie więcej przedsiębiorstw skorzystało ze wsparcia pochodzącego z funduszy Unii Europejskiej (ok. 20\% ogółu aktywnych innowacyjnie przedsiębiorstw przemysłowych) niż z środków krajowych (nieco ponad $11 \%$ ). Biorąc pod uwagę wsparcie krajowe, zauważa się, że udział przedsiębiorstw aktywnych innowacyjnie, które korzystały z tego rodzaju wsparcia, wzrastał wraz ze wzrostem wielkości przedsiębiorstw. W Polsce z tej formy dofinansowania skorzystało ok. 9\% małych przedsiębiorstw aktywnych innowacyjnie, wśród średnich ok. 13\%, a dużych ok. 15\%. Inne tendencje zaobserwowano $\mathrm{w}$ przypadku wsparcia pochodzącego z Unii Europejskiej. Tu największym beneficjentem pomocy były przedsiębiorstwa średnie. Niemal $1 / 4$ tej grupy aktywnych innowacyjnie podmiotów wykorzystała wsparcie unijne. W mniejszym stopniu z tej formy wsparcia 
publicznego skorzystały przedsiębiorstwa przemysłowe małe i duże. Wykazało ją w tych grupach po niemal 19\% i 18\% aktywnych innowacyjnie przedsiębiorstw.

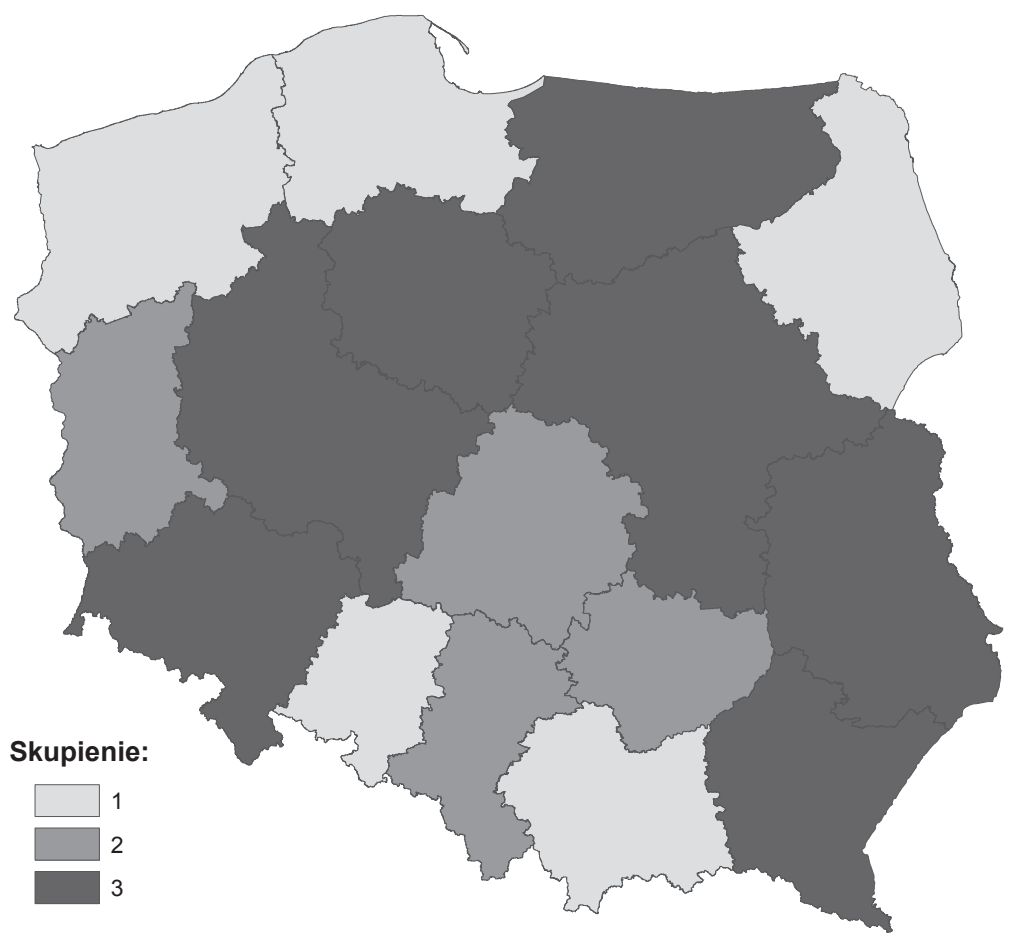

Ryc. 2. Skupienia województw podobnych pod względem udziału przedsiębiorstw przemysłowych, które w latach 2011-2013 otrzymały publiczne wsparcie ze środków krajowych i z UE w ogólnej liczbie przedsiębiorstw, które otrzymały publiczne wsparcie na działalność innowacyjną według wielkości

Źródło: opracowanie własne na podstawie danych GUS.

Przeprowadzone analizy wykazały, że obserwowane w skali Polski tendencje w zakresie wykorzystania badanych form publicznego wsparcia działań innowacyjnych przez przedsiębiorstwa przemysłowe mają różny przebieg w układach regionalnych. Poddana analizie aglomeracyjnej aktywność tych przedsiębiorstw w zakresie pozyskania wsparcia publicznego ze środków krajowych i unijnych z uwzględnieniem wielkości przedsiębiorstw pozwoliła wydzielić 3 skupienia województw (ryc. 2). 
Tab. 1. Średnie udziały przedsiębiorstw przemysłowych, które w latach 2011-2013 otrzymały publiczne wsparcie w ogólnej liczbie przedsiębiorstw, które otrzymały publiczne wsparcie na działalność innowacyjną według wielkości

\begin{tabular}{|c|c|c|c|c|c|c|}
\hline \multirow{2}{*}{$\begin{array}{c}\text { Skupie- } \\
\text { nia }\end{array}$} & \multicolumn{4}{|c|}{ Przedsiębiorstwa, które otrzymały wsparcie ze środków: } \\
\cline { 2 - 7 } & \multicolumn{3}{|c|}{ krajowych } & \multicolumn{3}{c|}{ UE } \\
\cline { 2 - 7 } & małe & średnie & duże & małe & średnie & duże \\
\hline 1 & 30,0 & 34,7 & 34,2 & 87,2 & 86,2 & 94,2 \\
\hline 2 & 21,2 & 48,6 & 73,6 & 92,9 & 80,9 & 66,2 \\
\hline 3 & 65,6 & 45,0 & 63,1 & 74,7 & 83,0 & 67,5 \\
\hline
\end{tabular}

Źródło: opracowanie własne na podstawie danych GUS.

Należy przy tym zauważyć, że na rozkład województw w skupieniach $\mathrm{w}$ najmniejszym stopniu wpływała sytuacja $\mathrm{w}$ przedsiębiorstwach średnich. Niezależnie od skupienia, w jakim się znalazły, odsetek tych, które otrzymały publiczne wsparcie tak krajowe, jak i z UE, oscylował wokół średniej dla tej grupy przedsiębiorstw w Polsce (odpowiednio ok. 44\% i $83 \%$ przedsiębiorstw). Województwa skupienia 1 cechuje bardzo wysokie zaangażowanie przedsiębiorstw dużych w pozyskiwanie środków na innowacje z UE (średnio ok. 90\% przedsiębiorstw, które otrzymały publiczne wsparcie) oraz znacznie niższa niż średnio w kraju aktywność przedsiębiorstw małych w pozyskiwaniu środków krajowych na ten cel (na poziomie ok. 31\% przedsiębiorstw małych, które pozyskały publiczne wsparcie na realizację działań innowacyjnych). $Z$ kolei zebrane w skupieniu 2 województwa cechowała wzmożona aktywność przedsiębiorstw małych w pozyskiwaniu środków na innowacje z UE (ok. 92\% przedsiębiorstw, które otrzymały publiczne wsparcie) oraz dużych ze środków krajowych (ok. $70 \%$ przedsiębiorstw dużych, które otrzymały publiczne wsparcie). Z kolei skupiające najwięcej województw skupienie 3 wyróżniała aktywność tak małych, jak i dużych podmiotów w zakresie uzyskiwania publicznych środków na działalność innowacyjną pochodzących ze źródeł krajowych (odpowiednio ok. 69\% przedsiębiorstw małych, które otrzymały publiczne wsparcie, i $62 \%$ przedsiębiorstw dużych, które otrzymały publiczne wsparcie). W tym skupieniu wśród przedsiębiorstw małych, które otrzymały wsparcie, ok. 3/4 korzystała także ze środków UE. Natomiast tak w skupieniu 2, jak i 3 publiczne wsparcie ze środków unijnych otrzymało ok. $2 / 3$ du- 
żych przedsiębiorstw, które w ogóle z publicznego wsparcia na działalność innowacyjną korzystały.

Poddane analizie wykorzystanie w latach 2011-2013 publicznego wsparcia na działania innowacyjne w przedsiębiorstwach przemysłowych wskazuje, że większość przedsiębiorstw pozyskiwała je na wsparcie inwestycji.

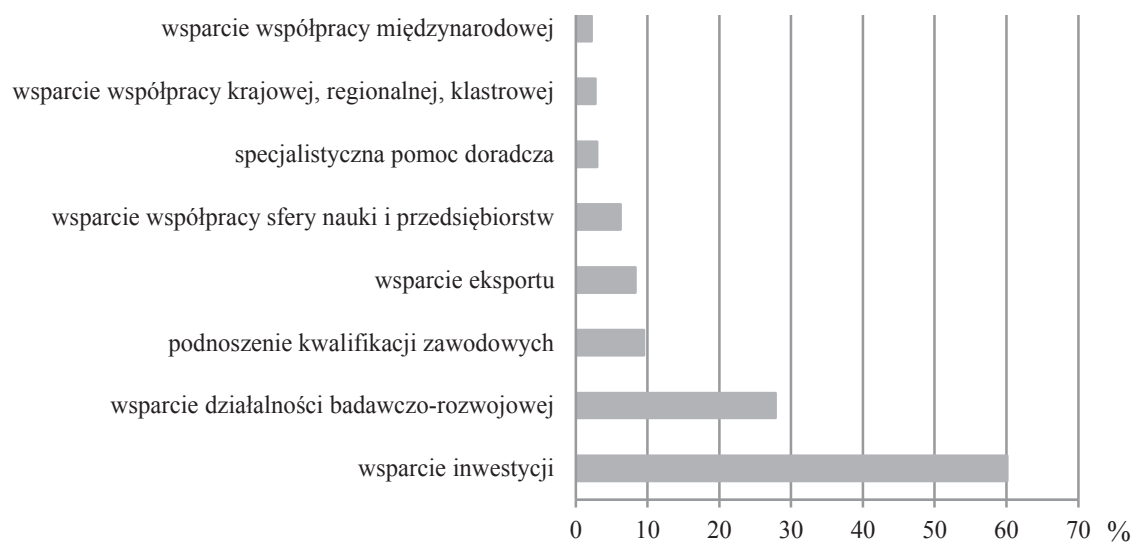

Ryc. 3. Udział przedsiębiorstw przemysłowych, które otrzymały publiczne wsparcie w ogólnej liczbie przedsiębiorstw, które w latach 2011-2013 otrzymały publiczne wsparcie na działalność innowacyjną według wybranych form

Źródło: opracowanie własne na podstawie danych GUS.

Przedstawiony na ryc. 3 rozkład zaangażowania przedsiębiorstw przemysłowych w pozyskiwanie publicznego wsparcia działalności innowacyjnej był zbliżony niezależnie od wielkości przedsiębiorstw. O ile średnio w Polsce z programów na wsparcie inwestycji skorzystało ponad $60 \%$ podmiotów przemysłowych, które otrzymały wsparcie na działalność innowacyjną ze środków publicznych, to wśród podmiotów małych i średnich było to nieco ponad $60 \%$, a w grupie dużych nieco ponad $50 \%$. Jednakże w układach regionalnych rozkład przedsiębiorstw, które skorzystały z publicznych środków pochodzących z programów na wsparcie inwestycji, był zróżnicowany. Odsetek podmiotów przemysłowych, które otrzymały publiczne wsparcie na ten cel w ogólnej liczbie przedsiębiorstw, które otrzymały wsparcie, wahał się od ok. 44\% w województwie świętokrzyskim do ok. $77 \%$ na terenie województwa warmińsko-mazurskiego. Biorąc pod uwagę grupy wielkości przedsiębiorstw, zauważa się, że największy udział przedsiębiorstw przemysłowych korzystających ze środków publicznych 
na wsparcia inwestycji był wśród podmiotów małych działających w województwie warmińsko-mazurskim, wśród podmiotów średnich na terenie województwa zachodniopomorskiego, a w grupie przedsiębiorstw dużych na terenie województwa kujawsko-pomorskiego. W analizowanym okresie wynosił on odpowiednio ok. 90\%, 77\% i 80\%.

Aktywność przedsiębiorstw w zakresie pozyskiwania funduszy publicznych z programów wspierających inwestycje wśród przedsiębiorstw przemysłowych podejmujących działalność innowacyjną znalazła odzwierciedlenie w strukturze nakładów ponoszonych na działalność innowacyjną przez tę grupę przedsiębiorstw. Jak wynika z danych GUS, w 2013 roku ponad $73 \%$ ogólnej kwoty wydatków przeznaczanych przez polski przemysł na działalność innowacyjną kierowanych było na inwestycje na środki trwałe.

Obok wsparcia inwestycji polskie przedsiębiorstwa przemysłowe, które w latach 2011-2013 korzystały z publicznego wsparcia działalności innowacyjnej, często partycypowały w programach wspierających działalność badawczo-rozwojową. Fundusze z programów przeznaczonych na wsparcie tej działalności wykorzystało ok. 30\% ogółu podmiotów przemysłowych, które w analizowanym okresie skorzystały z publicznych środków na wsparcie działalności innowacyjnej. Podobnie jak w przypadku rozkładu przedsiębiorstw korzystających z funduszy publicznych na inwestycje, udział przedsiębiorstw przemysłowych, które otrzymały środki na wsparcie działalności badawczo-rozwojowej w ogólnej liczbie podmiotów przemysłowych, które otrzymały wsparcie ze środków publicznych, był zróżnicowany przestrzennie. Wahał się od ok. $7 \% \mathrm{w}$ województwie podlaskim do ok. 41\% w województwie opolskim. Należy zwrócić uwagę, że odsetek podmiotów, które uzyskały takie wsparcie, wzrastał wraz ze wzrostem wielkości przedsiębiorstw. W grupie podmiotów małych wyniósł nieco ponad $18 \%$, średnich - nieco ponad $28 \%$, a dużych niemal $50 \%$. W układach wojewódzkich wśród przedsiębiorstw małych najaktywniejsze w zakresie pozyskiwania funduszy publicznych na wsparcie działalności badawczo-rozwojowej były podmioty z terenu województwa kujawsko-pomorskiego. Na tym terenie wśród ogółu przedsiębiorstw małych, które otrzymały publiczne wsparcie przeznaczone na działalność innowacyjną, połowa otrzymała środki na wsparcie działalności badawczo-rozwojowej. W tym zakresie w grupie podmiotów średnich najaktywniejsze były przedsiębiorstwa działające w województwach dolnośląskim i opolskim - stanowiły po ok. $42 \%$ przedsiębiorstw, które otrzymały publiczne wsparcie. Natomiast $100 \%$ aktywnych innowacyjnie dużych przedsiębiorstw przemysłowych 
otrzymało wsparcie publiczne z programów wsparcia działalności badawczo-rozwojowej w województwie opolskim.

Aktywność przedsiębiorstw w zakresie wykorzystania środków z innych programów była znacznie mniejsza. W skali Polski udział przedsiębiorstw, które otrzymały wsparcie publiczne, wahał się od ok. 2\% w przypadku tych, które skorzystały z funduszy na wsparcie współpracy międzynarodowej, do 9,5\% w przypadku podmiotów, które skorzystały ze wsparcia na podnoszenie kwalifikacji zawodowych. Analizując udział przedsiębiorstw przemysłowych korzystających z programów (poza programami na wsparcie inwestycji i działalność badawczo-rozwojową) według wielkości, zauważa się, że podmioty małe i średnie nieco częściej korzystały z publicznego wsparcia eksportu, a przedsiębiorstwa duże chętniej korzystały z publicznych funduszy na podnoszenie kwalifikacji zawodowych. Rozpatrując przestrzenny rozkład wykorzystania funduszy publicznych z wyłączeniem wparcia inwestycji i działalności badawczo-rozwojowej, warto zwrócić uwagę na wzmożoną aktywność w zakresie pozyskania funduszy na podnoszenie kwalifikacji zawodowych przedsiębiorstw z terenu województwa kujawsko-pomorskiego (15\% ogółu podmiotów, które w rozpatrywanym okresie otrzymały publiczne wsparcie na ten cel) oraz w zakresie pozyskania środków publicznych na wsparcie eksportu przedsiębiorstw z terenu województwa opolskiego (22\%).

\section{PODSUMOWANIE}

Z przeprowadzonej analizy wynika, że aktywność polskich przedsiębiorstw przemysłowych w zakresie pozyskiwania wsparcia publicznego dla działalności innowacyjnej nie jest zbyt duża, ale występują spore różnice w ich pozyskiwaniu ze względu na wielkość przedsiębiorstw i lokalizację przestrzenną. Zauważa się, że w latach 2011-2013 znacznie więcej aktywnych innowacyjnie przedsiębiorstw przemysłowych korzystało z środków pochodzących z UE (ok. 20\%) niż funduszy krajowych (11\%). W analizowanym okresie aktywniejsze w tym zakresie były przedsiębiorstwa średnie i małe. Duże podmioty w większym stopniu wykorzystywały środki pochodzące ze źródeł krajowych.

Poddane analizie aglomeracyjnej postawy przedsiębiorstw przemysłowych pod względem ich aktywności w zakresie wykorzystania instrumentów publicznego wsparcia innowacji ze środków krajowych i unijnych z uwzględnieniem wielkości przedsiębiorstw w okresie 2011-2013 
pozwoliły wydzielić 3 skupienia województw. Podobna pod względem analizowanych zmiennych aktywność przedsiębiorstw nie była uwarunkowana ich sąsiedztwem przestrzennym. Skupienie koncentrujące najwięcej województw wyróżniała aktywność tak małych, jak i dużych podmiotów w zakresie uzyskiwania publicznych środków na działalność innowacyjną pochodzących ze źródeł krajowych. Pozyskało je ok. 60-70\% przedsiębiorstw, które otrzymały publiczne wsparcie. Ponadto w województwach przynależnych do tego skupienia zwracała uwagę aktywność przedsiębiorstw małych $\mathrm{w}$ zakresie pozyskania wsparcia na innowacje ze środków unijnych. Pozyskało je ok. $3 / 4$ tych, które otrzymały wsparcie.

Przeprowadzone analizy wykazały również znaczne zróżnicowanie przestrzenne w pozyskiwaniu funduszy publicznych na wsparcie działalności innowacyjnej. Biorąc pod uwagę przeznaczenie tych środków, niezależnie od wielkości i lokalizacji podmiotów gospodarczych zasadniczo największy odsetek przedsiębiorstw korzystających ze wsparcia publicznego pozyskiwał fundusze na wsparcie inwestycji.

Uwagę zwraca duża różnica między udziałem podmiotów pozyskujących wsparcie na inwestycje i na działalność badawczo-rozwojową. Znajdująca potwierdzenie w strukturze nakładów na działalność innowacyjną w przedsiębiorstwach przemysłowych ta strategia wydatków inwestycyjnych wskazuje, że polskie przedsiębiorstwa wciąż w największym stopniu dążą do zapełnienia luki technologicznej. Przedkładając wydatki na środki trwałe nad działalność badawczo-rozwojową, rozwój kompetentnych kadr czy szeroko rozumianą współpracę, spowalniają możliwość budowania gospodarki opartej na wiedzy i związanej z nią konkurencyjności bazującej na innowacjach. Wskazuje na to poziom innowacyjności polskiego przemysłu. Od 2009 roku udział przedsiębiorstw przemysłowych wdrażających innowacje w ogólnej liczbie przedsiębiorstw przemysłowych nie przekroczył $20 \%$.

\section{LITERATURA}

Audretsch D. (2001), Research issues relating to structure, competition, and performance of small technology-based firms. Small Business Economics, Vol. 16, Nr 1. Kluwer Academic Publishers, Printed in the Nederlands.

Bukowski M., Szpor A., Śniegocki A. (2012), Potencjat i barier polskiej innowacyjności, Instytut Badań Strukturalnych, Warszawa. 
http://www.pi.gov.pl/PARPFiles/media/_multimedia/C447085F017A4547B51F37A08127B160/20120309_115644\%20Potencjal\%20i\%20bariery\%20 polskiej\%20innowacyjnosci.pdf [25.02.2015].

Everitt B.S., Landau S., Leese M., Stahl D. (2011), Cluster analysis, 5th Edition. Wiley Series in Probability and Statistics. DOI: 10.1002/9780470977811. index

Frąś J. (2013), Zarządzanie procesem wdrażania innowacji w przedsiębiorstwie, Studia i Prace Wydziału Nauk Ekonomicznych i Zarządzania, nr 34, Wydawnictwo Naukowe Uniwersytetu Szczecińskiego, Szczecin. http://www. wneiz.pl/nauka_wneiz/sip/sip34-2013/SiP-34-t1-175.pdf [2.02.2015].

Gierańczyk W., Kordowska A., (2014), Cele działalności, przeszkody oraz konkurencyjność innowacji $w$ opinii przedsiębiorstw przemysłowych $w$ województwie kujawsko-pomorskim w latach 2010-2012, „Marketing i Rynek”, nr 10.

Griffith R., Redding S., Van Reenen J. (2001), Measuring the cost-effectiveness of an R\&D tax credit for the UK, "Fiscal Studies", Vol. 22, No. 3, Institute for Fisical Studies, London. http://dx.doi.org/10.1111/j.1475-5890.2001. tb00047.x. [25.02.2015].

Głodek P., Gołębiowski M. (2006), Vademecum innowacyjnego przedsiębiorcy. Finansowanie innowacji $w$ małych $i$ średnich przedsiębiorstwach, Warszawa, http://www.rsi.org.pl/dane/download/vademekum_2tom_finansowanie_innowacji.pdf [26.02.2015].

Hettne B. (1983), The development of development theory, "Acta Sociologica" 26 (3/4). http://dx.doi.org/10.1177/000169938302600303 [25.02.2015].

http://inwestor.msp.gov.pl/si/polska-gospodarka/wiadomosci-gospodarcze/25869, Obecny-stan-aktywnosci-innowacyjnej-polskich-przedsiebiorstw.html [19.02.2014].

Krueger A.O. (1968), Factor endowments and per capita income differences among countries, "Economic Journal” 78(311), http://dx.doi.org/10.2307/2229388 [22.02.2015].

Limański,A. (2011), Rola innowacyjności w budowaniu przewagi konkurencyjnej przedsiębiorstwa $w$ gospodarce opartej na wiedzy, Nierówności społeczne a wzrost gospodarczy 23, Uniwersytet Rzeszowski, Rzeszów.

Low D., Chapman R. (2007), Inter-relationships between innovation and market orientation of SMEs, "Management Research News" Vol. 30, Nr 12, Emerald Group Publishing, Bradford.

Lucas R.E. (1988), On the Mechanics of Economic Development, "Journal of Monetary Economics", 22: 3-42, Elsevier Science Publishers B.V., North Holland, http://dx.doi. org/10.1016/0304-3932(88)90168-7 [25.02.2015]. 
Matsuyama K. (1992), Innovation and growth in the global economy, "Journal of International Economy" 33(3-4). http://dx.doi.org/10.1016/00221996(92)90011-8 [23.02.2015].

Mazumdar K. (2005), Socio-economic factors determining adult literacy in developing countries, International Journal of Social Economics 32(1/2), http:// dx.doi.org/10.110\%208/03068290510575667 (25.02.2015).

Niedzielski P, Rychlik K. (2006), Innowacje i kreatywność, Wydawnictwo Uniwersytetu Szczecińskiego, Szczecin.

Piecuch T. (2010), Funkcjonowanie matych $i$ średnich przedsiębiorstw w gospodarce. W: M. Matejuna (red.), Wyzwania i perspektywy zarzadzania w matych i średnich przedsiębiorstwach, Wydawnictwo C.H. Beck, Warszawa.

Piersiala L., Nowakowska-Grunt J. (2014), Rola polityki gospodarczej w rozwoju innowacyjnych przedsiębiorstw, „Ekonomia i Zarządzanie” Vol. 6, no. 3, DOI: 10.12846/j.em.2014.03.10 [26.02.2015].

Przychodzeń J. (2013), Realizacja polityki w zakresie wspierania innowacyjności $w$ Polsce w okresie ostatniego kryzysu finansowego, Management and $\mathrm{Bu}-$ siness Administration. Central Europe Vol. 21, No. 2(121). Copyright by Akademia Leona Koźmińskiego. http://dx.doi.org/10.7206/mba.ce.20843356.62 [22.02.2015].

Schumacher E.F. (1979), Małe jest piękne, PIW, Warszawa.

Sawa Ł. (2013), Obecny stan aktywności innowacyjnej polskich przedsiębiorstw, Ministerstwo Skarbu Państwa, http://inwestor.msp.gov.pl/si/polska-gospodarka/wiadomosci gospodarcze/25869, Obecny-stan-aktywnosciinnowacyjnej-polskich-przedsiebiorstw.html?search $=96460$.

Sen A. (1983), Development: Which way now?, "The Economic Journal” 93(372), http://dx.doi.org/10.2307/2232744.

Stawasz E. (2010), Rozwój badań nad innowacyjnościa małych $i$ średnich przedsiębiorstw w Polsce. W: Błaszczyk W., Bednarska-Wnuk I., Kuźbik P. (red.), Nurt metodologiczny w naukach o zarzadzaniu, Acta Universitatis Lodziensis, Folia Oeconomica, Łódź.

Stawasz E. (2011), Polityka innowacyjna wobec MS, „Zeszyty Naukowe” nr 654, „Ekonomiczne Problemy Usług”, nr 70, Uniwersytet Szczeciński, Szczecin, http://www.wzieu.pl/zn/654/ZN_654.pdf [17.02.2015].

Stanisz A. (2007), Przystępny kurs statystyki z zastosowaniem STATISTICA PL na przykładach z medycyny, Analizy wielowymiarowe t. 3, StatSoft, Kraków.

Tidd J., Bessant J., Pavitt K. (2005), Managing innovation. Integrating technological, market and organizational change, J. Wiley \& Sons, Ltd, New York.

Tidd J., Bessant J. (2011), Zarzadzanie innowacjami. Integracja zmian technologicznych, rynkowych i organizacyjnych, Wolters Kluwer, Warszawa. 
Wieser R. (2005), Research and development productivity and spillovers: Empirical evidence at the firm level, "Journal of Economic Surveys" Vol. 19, No. 4/2005, http://dx.doi.org/10.1111/j.0950-0804.2005.00260.x. [25.02.2015].

\title{
REGIONAL DIFFERENCES IN THE ACTIVITY OF INDUSTRIAL ENTERPRISES IN THE USE OF PUBLIC FINANCIAL INSTRUMENTS TO SUPPORT INNOVATION IN THE PERIOD 2011-2013
}

\begin{abstract}
Innovations are usually associated with the progress and modernity, and when they spread to the sphere of the functioning, they highly contribute to the economic development. They are impulsion of the economic growth because of their role of a specific entrepreneurship tool. Although the benefits of being innovative are widely known and accepted, the innovative activity of Polish enterprises is not large. One of the major barriers to the innovation process are costs. Often exceed the capabilities of enterprises. Currently on the Polish market there are instruments available to help finance innovation, this article analyzes the activity of industrial enterprises in the use of financial instruments of public support for innovation. Takes into account the size of innovation active industrial enterprises and their location by provinces. Analyzes both the use of domestic support, as well as with the EU, also examined targeted programs in area of which such support is granted. The basis for the analysis were the GUS data PNT-02 study carried out in 2014.
\end{abstract}

Keywords: competitiveness; innovation activities; public support for innovation. 